\title{
EDUCATION IN SMART CITIES: PRACTICES AND CHALLENGES
}

\author{
Andreea Molnar \\ Swinburne University of Technology, Melbourne, Australia
}

\begin{abstract}
Education is one of the main services offered by the government. Within the advent of smart cities, smart education is defined as the education strategy for smart cities and the concept is becoming more popular with the advent of smart cities. This research aims to address the role of education in smart cities context by providing an overview of the current practices and discussing some of the challenges that exist in delivering education within this context. The following challenges have been identified: advocating for technology, the risk of increasing the rural-urban divide, multidisciplinary of the field and the existence of different definitions of what a smart city is.
\end{abstract}

\section{KEYWORDS}

Education, Smart Cities, Smart Learning, Smart Education

\section{INTRODUCTION}

As the world population is increasing and moving towards cities, governments around the world have invested in the idea of smart cities, which will ensure a good quality of life and the best access to services for their citizens. The smart cities concept was introduced in 1994 (Dameri \& Cocchia, 2013) and since then has been increasingly used. Despite it being mentioned for most than 20 years, there is still not a clear definition of what a smart city is and different definitions have been used focused on different aspects of what a smart city is (see Gil-Garcia et al., (2015) for an overview of different smart cities definitions). The reason for the multitude of smart cities definitions is summarized by the Yigitcanlar et al. (2018):

"the fast-growing literature on smart cities comes from the streams of academic, commercial and (inter)national organisations researching on and practicing smart cities. These groups have a different take on the concept as they see it from different lenses such as disciplinary, practice-or conceptualisation-orientation, and domain-orientation, e.g., technology, economy, society, environment, governance."

Some definitions focus on the technical aspects of the smart cities, while others consider also the human and institutional dimensions (Caprotti, 2018). Most of the technology-centric definitions view technology as an enabler to improve the life of the smart cities inhabitant as Washburn et al. (2009) mentions:

"The use of Smart Computing technologies to make the critical infrastructure components and services of a city-which include city administration, education, healthcare, public safety, real estate, transportation, and utilities-more intelligent, interconnected, and efficient".

According to Ahvenniemi et al. (2017), the two elements most mentioned in the discussion of the smart cities are the technology and people, however other elements are also essential. For example, social infrastructure is important for a smart city to allow "connecting people and creating relationships (Alawadhi et al., 2012). Smart cities aim to address various issues such as mobility, clean energy, water distribution, food production and distribution, healthcare and public involvement (Hollands, 2008), all with the aim to increase the quality of life for their inhabitants.

A key driver of a smart city is creativity and as a result education, learning and knowledge are at the core of a smart city (Thuzar, 2011). Therefore, a smart city is a city which has educated individual and skills workforces (Winters, 2011). Smart cities will act as a magnet for educated and creative people and "this allows the creation of a virtuous circle making them smarter and smarter" (Albino et al., 2015). As smart cities research evolves, different other concepts such as smart education and smart universities emerge. The 
aim of this paper is to provide preliminary findings on our literature review on education in the context of the smart cities. The article will identify some current practices and challenges. The rest of this paper is organized as follows. The next section identifies current practices of education in smart cities context. The following section identifies some of the existing challenges of doing research in the field. The subsequent section briefly describes the limitations of the findings. The paper ends with our conclusion.

\section{CURRENT PRACTICES}

Education is key in understanding, explaining and addressing the challenges with whom the society confronts with (Visvizi et al., 2018). Technology-enhanced learning is often a part of smart cities education strategies and it has been used for various aims. For example, technology has been used in education with the aim of reaching as many people as possible (Weerakkody et al., 2014), complementing existing ways to teach and engage with difficult concepts (Molnar, 2019) or as a mean to help teachers find existing educational resources which might be useful in their classroom (London et al., 2018). Technology adoption has been motivated by improving the quality of education (del Río et al., 2019; Tlili et al., 2019), motivating students (del Río et al., 2019), finding alternative solutions to deliver content that it is difficult to understand or costly and difficult to reproduce in a classroom environment (Molnar, 2017) and increasing access to mobile technology and their usage by their owners for learning (Molnar, 2014). The use of technology allows to personalize the learning and provide a tailored experience to the students which might otherwise be difficult to achieve especially at large scale (Popleteev et al., 2013; Tlili et al., 2019).

In some cases, technology is considered a vital element of universities (Semenova et al., 2017). Universities that use technology to improve performance and their students' employability are sometimes referred to in the literature as smart universities (Aldowah et al., 2017). Smart education is sometimes defined as both the education provided by smart cities but also as a "natural stage of e-learning development" (Semenova et al., 2017) however, being smart does not imply simply "intelligent" or only "digital" (Giovannella, 2014).

According to Kim and Oh (2014), there are five dimensions in the "smart education": Self-directed, Motivated, Adapted, Resource enriched and Technology-embedded, which together form the SMART acronym. Concepts such as smart learning and smart pedagogies are used focusing on how learning could be facilitated by smart technology to be personalized to students experience and leading to self-directed and motivated learners (Kim and Oh, 2014; Bognar et al., 2019).

In the smart city context, education is one of the services smart cities offers and one of the human elements related to smart cities (Anthopoulos et al., 2019). Education is considered to be a crucial element for the creation of smart cities due to the need to improve social development and growth in smart cities (Letaifa, 2015). Letaifa (2015) argues that one of the indicators of a smart city is "smart people". Different cities have integrated education as one of the things in their aim to become smart cities. For example, Singapore has a 10 -year master plan to become an intelligent island. Among the objectives included in that master plan is the use of technology in education, to connect students in and out of Singapore (Infocomm, 2012). Barcelona is another example of considering the educational aspect of the smart city approach. They have created a campus that "promotes cooperation and synergies between local, national and international companies, universities, research centers, SMEs and local entrepreneurs" (Boes et al., 2016). Amsterdam has set-up the Amsterdam Institute for Advanced Metropolitan Solutions (AMS) that aims "to encourage education of residents and smart solutions for metropolitan area" (Boes et al., 2016). Similar to Barcelona's case this institute facilitates the collaboration between public, private and academic partners. Helsinki, there has been set up a hub which aims to attract creative and knowledgeable people (Boes et al., 2016). Wuhan is often emphasis education credentials in its smart cities vision (Cowley et al., 2018). Tele-education has been used as means to inform and create awareness among citizens about recycling and energy savings (Alexopoulous et al., 2018) or to increase the level of outreach for ITC education for senior citizens (Molnar et al., 2014).

Education has also increasingly recognized as a need to improve to empower citizens and facilitate a more active role in smart cities initiatives (Hudson et al., 2019). Universities are argued to be significant agents which could influence entrepreneurial dynamics in the smart cities context (Santos, 2018). The presence of a creative class and level of education are among the factors which correlated with urban smartness (Caragliu et al., 2009) and thus cities cannot "achieve smartness without creativity, education, 
knowledge and learning" (Arroub et al., 2016). Some authors argue that the quality of the cities depends on the quality of the schools (Vincent, 2006) and that there is a need to integrate education institutions via strategic plans as a solution to regions problems (Ortiz-Fournier et al., 2010).

\section{CHALLENGES}

Smart cities field and education in smart cities is an emerging field. Through the literature review, several challenges have been identified.

- Advocating for technology: the field is technology focused. For example, a smart learning environment is described as being "based on smart devices and intelligent technologies" (Bognar et al., 2019). However, when advocacy and analysis are interlinked this can create challenges (Molnar et al., 2015) in interpreting the results. The technology has indeed the potential to support and improve education, however, the technology could also deter learning depending on how it is used (Kuznekoff et al., 2015). There are various factors that impede technology adoption in education and these are not always technology related.

- Rural vs urban divide: The focus on smart cities and focusing resources towards them might lead towards disadvantages towards rural communities and education offered in rural areas (Eppley \& Shannon, 2015).

- Cross, inter, trans multidisciplinary of the field: Durán-Sánchez et al. (2018) have shown that the articles in the field could be from social science or computer science and engineering. A field which is so cross, inter, trans, multidisciplinary could lead to difficulties in keeping up and understanding the research approaches in different domains (Molnar et al., 2015). This could lead to difficulties in having a common language and a single definition of what different aspects of the domain are. For example, the field uses different terms such as smart education, smart pedagogies, smart learning, smart people, but these have different meanings. The research in the area comes from a variety of disciplines (Yigitcanlar et al. 2018) which all look through the lens of their field and have different thresholds and methods of measuring the quality. This could be both an advantage as different perspectives are being addressed, but it in fields such as e-government it has led also in difficulties in the perception of the quality of work coming from different disciplines (Dwivedi, 2013).

- Definition: Smart cities means different things for different people. Cities have earned the 'smart' tag based on different reasons and different criteria (Bhatia, 2018). This makes it difficult to determine the role of education in the context of smart cities. It is also not clear how 'smart education' or the education for smart cities differs from education which is not necessarily happening in a city which classified as a smart city. Sometimes smart education is also used as a term referring to the use of artificial intelligence in education (El Mhouti \& Erradi, 2018), without having necessarily a connection with the smart city. Without a clear definition it is hard to ensure the same understanding and as a result hard to replicate studies due to a different understanding of the context in which they happen.

Although all the above challenges need to be considered these challenges could be seen also as opportunities for the smart cities. For example, the technology could support different aspects of education and there is evidence that technology use could improve learning and the multidisciplinary of the field could lead to novel solutions that would enhance the quality of education.

\section{CONCLUSIONS AND LIMITATIONS}

Smart cities are a complex phenomenon and although the main focus it is on technology, public services such as education are considered an essential part of having citizens prepared to engage with them and improve creativity and job prospects. This article has highlighted several of the smart cities initiatives in which education has been considered as part of the smart city initiative. The shift is focused to empower learners to be self-directed and motivated and the technology is seen as the core of the process. The articles have identified also several challenges (focus on technology, the danger of increasing rural vs urban divide, multidisciplinary of the field and the lack of a clear understanding of what smart means) which could provide further research directions in the field. 
This article does not provide a systematic literature review of the work on the topic and as such there are educational initiates within might cities that have not been identified. The list of identified challenges in the field is also not exhaustive. To provide a comprehensive picture of the research in the field a systematic review needs to be performed.

\section{REFERENCES}

Ahvenniemi, H., Huovila, A., Pinto-Seppä, I., and Airaksinen, M. 2017. What are the differences between sustainable and smart cities?, Cities (60), pp. 234-245.

Alawadhi, S., Aldama-Nalda, A., Chourabi, H., Gil-Garcia, J.R., Leung, S. Mellouli, S., Nam, T., Pardo, T.A., Scholl, H.J., and Walker, S. 2012.Building Understanding of Smart City Initiatives, Lecture Notes in Computer Science (7443), pp. 40-53. doi: 10.1007/978-3-642-33489-4_4

Albino, V., Berardi, U., and Dangelico, R. M. 2015. Smart cities: Definitions, Dimensions, Performance, and Initiatives, Journal of Urban Technology (22:1), pp. 3-21.

Aldowah, H., Rehman, S. U., Ghazal, S., \& Umar, I. N. 2017. Internet of Things in higher education: a study on future learning. In Journal of Physics: Conference Series (Vol. 892, No. 1, p. 012017). IOP Publishing.

Anthopoulos, L., Janssen, M., and Weerakkody, V. 2019. A Unified Smart City Model (USCM) for Smart City Conceptualization and Benchmarking, In Smart Cities and Smart Spaces: Concepts, Methodologies, Tools, and Applications (pp. 247-264). IGI Global.

Arroub, A., Zahi, B., Sabir, E., and Sadik, M. 2016. A literature review on Smart Cities: Paradigms, opportunities and open problems. In 2016 International Conference on Wireless Networks and Mobile Communications, pp. 180-186.

Bhatia, S. (2018). Sustainable Smart Universities for Smart Cities. JEMT, (21:12), pp. 1-11.

Boes, K., Buhalis, D., and Inversini, A. 2016. Smart Tourism Destinations: Ecosystems for Tourism Destination Competitiveness, International Journal of Tourism Cities (2:2), pp.108-124.

Bognar, B., Sablić, M., and Škugor, A. 2019. Flipped Learning and Online Discussion in Higher Education Teaching, In Didactics of Smart Pedagogy (pp. 371-392). Springer, Cham.

Caprotti, F. 2018. Future Cities: Moving from Technical to Human Needs, Palgrave Communications (4:1), no. 35.

Caragliu, A., Del Bo, C., and Nijkamp, P. 2011. Smart Cities in Europe, Journal of Urban technology, 18(2), pp. 65-82.

Cowley, R., Caprotti, F., Ferretti, M., and Zhong, C. 2018. Ordinary Chinese Smart Cities: The Case of Wuhan, In Inside Smart Cities (pp. 45-64). Routledge.

Dameri, R. P., and Cocchia, A. 2013. Smart city and digital city: twenty years of terminology evolution. In X Conference of the Italian Chapter of AIS, ITAIS (pp. 1-8).

del Río, N. G., González-González, C. S., Martín-González, R., Navarro-Adelantado, V., Toledo-Delgado, P., \& García-Peñalvo, F. 2019. Effects of a Gamified Educational Program in the Nutrition of Children with Obesity. Journal of medical systems, 43(7), 198.

Durán-Sánchez, A., Álvarez-García, J., Del Río-Rama, M. C., \& Sarango-Lalangui, P. O. 2018. Analysis of the scientific literature published on smart learning. Espacios, 39(10), 14-27.

Dwivedi, Y. K. 2013. Through the Eyes of the eGov Scholarly Community: Perceptions of the Quality of Journals Publishing Electronic Government Research, Journal of Enterprise Information Management (26:3), pp. 207-217.

El Mhouti, A., \& Erradi, M. 2018, October. Towards a Smart Learning Management System (smart-LMS) to Improve Collaborative Learning in Higher Education. In Proceedings of the 3rd International Conference on Smart City Applications(p. 7). ACM.

Eppley, K., \& Shannon, P. 2015. Literacy education for the Lumps and Divots of smart cities and rural places. The politics of educational opportunity in rural contexts, 59-73.

Gil-Garcia, J. R., Pardo, T. A., and Nam, T. 2015. What Makes a City Smart? Identifying Core Components and Proposing an Integrative and Comprehensive Conceptualization, Information Polity,(20:1),61-87.

Giovannella, C. 2014. Smart Learning Eco-Systems:"fashion" or "beef'?. Journal of e-Learning and Knowledge Society, 10(3).

Hollands, R. G. 2008. Will the Real Smart City Please Stand Up? Intelligent, progressive or entrepreneurial?. City, (12:3), pp. 303-320.

Hudson, L., Wolff, A., Gooch, D., van der Linden, J., Kortuem, G., Petre, M., teen Veen, R., and O'Connor-Gotra, S. 2019. Supporting Urban Change: Using a MOOC to Facilitate Attitudinal Learning and Participation in Smart Cities, Computers \& Education (129), pp. 37-47. 
Infocomm. 2012. Info-Communications Development Authority of Singapore. Accessed February 12, 2019, available at: https://www.imda.gov.sg/-/media/imda/files/regulation-licensing-and-consultations/frameworks-andpolicies/competition-management/telecom-competition-code/23-telecomcontenderoffer.pdf?la=en

Kim, B. H., and Oh, S. Y. 2014. A Study on the SMART Education System Based on Cloud and N-screen, Journal of the Korea Academia-Industrial cooperation Society (15:1), pp. 137-143.

Kuznekoff, J. H., Munz, S., \& Titsworth, S. 2015. Mobile phones in the classroom: Examining the effects of texting, Twitter, and message content on student learning. Communication Education, 64(3), 344-365.

Letaifa, S. B. 2015. How to Strategize Smart Cities: Revealing the SMART Model, Journal of Business Research (68:7), pp. 1414-1419.

London, J. S., McKenna, A., Huang, W., Molnar, A., and Cruz, S. N. 2018. The Role of the Visualization Tool DIA2 in Supporting STEM Researchers, Educators, and Administrators, International Journal of Engineering Education (34:3), pp. 1104-1119.

Molnar, A. 2014. On better understanding the usage of mobile phones for learning purposes. Bulletin of the IEEE Technical Committee on Learning Technology, 16(2-3), 18.

Molnar, A. 2017. Children as agents of change in combatting antibiotic resistance. Journal of health services research \& policy, 22(4), 258-260.

Molnar, A. 2019. Antimicrobial Resistance Awareness and Games. Trends in Microbiology (27:1), pp. 1-3.

Molnar, A., Janssen, M., and Weerakkody, V. 2015. E-Government Theories and Challenges: Findings from a Plenary Expert Panel, In 16th Annual International Conference on Digital Government Research (pp. 160-166). ACM.

Molnar, A., Weerakkody, V., \& Almuwil, A. 2014, September. Promoting ICT skills through online services: Case study of video use for adult education in municipalities. In IFIP International Conference on Artificial Intelligence Applications and Innovations (pp. 63-72). Springer, Berlin, Heidelberg.

Ortiz-Fournier, L. V., Márquez, E., Flores, F. R., Rivera-Vázquez, J. C., and Colon, P. A. 2010. Integrating Educational Institutions to Produce Intellectual Capital for Sustainability in Caguas, Puerto Rico, Knowledge Management Research \& Practice (8:3), pp. 203-215.

Popleteev, A., McCall, R., Molnar, A., \& Avanesov, T. (2013, June). Touch by touch: Promoting cultural awareness with multitouch gaming. In 2013 International Conference on Smart Communications in Network Technologies (SaCoNeT) (Vol. 4, pp. 1-4). IEEE.

Santos, D. 2018. The Role of Entrepreneurial Universities in Smart Cities, In Proceedings of the 3rd International Conference on Smart City Applications (p. 1). ACM.

Scholl, Hans J. 2019. Strategic Overhaul of Government Operations: Situated Action Analysis of Socio-Technical Innovation in the Public Sector. In Strategic Management and Innovative Applications of E-Government, pp. 72-106.

Semenova, N. V., Svyatkina, E. A., Pismak, T. G., \& Polezhaeva, Z. Y. (2017, September). The realities of smart education in the contemporary Russian Universities. In Proceedings of the Internationsl Conference on Electronic Governance and Open Society: Challenges in Eurasia (pp. 48-52). ACM.

Thuzar, M. 2011. Urbanization in SouthEast Asia: Developing Smart Cities for the Future?, Regional Outlook (183), pp. $96-100$.

Tlili, A., Denden, M., Essalmi, F., Jemni, M., Chang, M., Kinshuk, \& Chen, N. S. 2019. Automatic modeling learner's personality using learning analytics approach in an intelligent Moodle learning platform. Interactive Learning Environments, 1-15.

Vincent, J. M. 2006. Public Schools as Public Infrastructure: Roles for Planning Researchers, Journal of Planning Education and Research (25:4), pp. 433-437.

Visvizi, A., Lytras, M. D., and Daniela, L. 2018. (Re) Defining Smart Education: Towards Dynamic Education and Information Systems for Innovation Network, In Enhancing Knowledge Discovery and Innovation in the Digital Era (pp. 1-12). IGI Global.

Washburn, D., Sindhu, U., Balaouras, S., Dines, R. A., Hayes, N., and Nelson, L. E. 2009. Helping CIOs Understand "Smart City" Initiatives, Growth (17:2), pp. 1-17.

Weerakkody, V., Molnar, A., and El-Haddadeh, R. 2014. Indicators for Measuring the Success of Video Usage in Public Services: The Case of Education, In Americas Conference on Information Systems.

Winters, J.V. 2011. "Why are Smart Cities Growing? Who Moves and Who Stays," Journal of Regional Science (51: 2), pp. 253-270. doi: 10.1111/j.1467-9787.2010.00693.x

Yigitcanlar, T., Kamruzzaman, M., Foth, M., Sabatini, J., da Costa, E., and Ioppolo, G. 2018. Can Cities become Smart without being Sustainable? A Systematic Review of the Literature, Sustainable Cities and Society (45), pp. 348-365. 